УДК 378.147.091.33-027.22:[614.46:616-036.21]

DOI:

Тетяна Ситнік, доктор педагогічних наук, завідувач кафедри гуманітарних дисииплін Черкаської медичної академії

\title{
ОРГАНІЗАЦІЯ САМОСТІЙНОЇ РОБОТИ СТУДЕНТІВ В УМОВАХ КАРАНТИННИХ ОБМЕЖЕНЬ
}

Статтю присвячено з'ясуванню особливостей методики організації самостійної роботи студентів під час всесвітньої пандемії в умовах карантинних обмежень. Уній акцентовано увагу на характері змішаного навчання студентської молоді в закладах вищої освіти, щзо дає змогу викладачеві поєднувати аудиторні заняття з онлайн-діяльністю. Встановлено роль самостійної роботи та ї̈ специфіку під час дистанційного навчання, визначено переваги й недоліки окремих видів самостійної діяльності студентів в умовах карантинних обмежень. Висвітлено результати анкетування здобувачів освіти щуодо організації самостійної роботи під час зміманого навчання.

Ключові слова: самостійна робота студентів; заклади вищуӧ освіти; змішане навчання; онлайндіяльність; дистаниійна форма; ефективні види самостійної діяльності студентів.

תim. 8.

Tetiana Sytnik, Doctor of Sciences (Pedagogy), Head of the Humanities Department Cherkasy Medical Academy

\section{ORGANIZATION OF STUDENTS' INDIVIDUAL WORK IN CONDITIONS OF QUARANTINE RESTRICTIONS}

The article is dedicated to clarifying the features of the methodology of organizing the individual work of students during the global pandemic in the context of quarantine restrictions.

It focuses on the nature of blended learning of students in higher education institutions, which allows the teacher to combine classroom studies with online activities. An individual work of students has always been the focus of attention of teachers and methodologists. The scientific literature describes in detail the types and methods of organizing the individual work of students, in particular, work on the model, work with a summary, preparation of oral answers and written individual work, doing exercises, solving problems, preparing homework, writing coursework and qualification works, scientific papers for the competition, preparing for student olympiads, writing theses and scientific articles. However, this applies to the methodology of organizing individual work under the traditional training system. Therefore, the article establishes the place and role of individual work and its specificity during distance learning, identifies the advantages and disadvantages of certain types of individual activities of students under quarantine restrictions. The specifics of the organization of individual work of students under quarantine restrictions determine to carry it out in several stages. Important among them are the following: preliminary preparation, study of new material, training, practical tasks and reflection. These stages relate to both classroom studies (contact hours) and online activities of students. Each stage uses different methods of individual work, such as: watching a promo video, infographic review (graphs, diagrams, charts with content), diagnostic testing (stage of preliminary preparation); video, audio recordings, presentation, work with cases, video conference, setting problematic questions during communication with students (the stage of studying new material); discussion of certain issues, conducting debates, discussions, role-playing games, performing practical group/individual tasks without evaluation (training stage); individual search by students for answers to questions, performing virtual laboratory works, multilevel individual and group; interactive practical tasks (the stage of practical tasks); development of lecture notes, memory cards, keeping a journal, answers to reflexive questions, presentations (reflection stage) etc. The article also covers the results of the survey of educational applicants on the organization of individual work during blended learning.

Keywords: the students' individual work; higher education institutions; blended learning; online activities; distance form; effective types of individual activities of students.

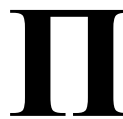
остановка проблеми. На початку 2020 p. у зв'язку зі світовою пандемією в Україні були введені карантинні обмеження щодо організації проведення навчання у середніх і вищих закладах освіти. Це і спонукало Міністерство освіти і науки України рекомендувати освітнім закладам вдаватися до дистанційного навчання, а згодом перейти на змішану форму. Змішане навчання дає змогу ефективно поєднувати заняття в аудиторіях 3 онлайн-діяльністю студентів. Уведення дистанційної форми співпраці викладача зі студентами, що становить основу змішаного навчання, сприяло активізації самостійної роботи 


\section{ОРГАНІЗАЦІЯ САМОСТІЙНОӤ РОБОТИСТУДЕНТІВ В УМОВАХ КАРАНТИННИХОБМЕЖЕНЬ}

здобувачів вищої освіти. Проблема самостійної роботи $є$ не новою у педагогічній діяльності викладачів, проте повністю використовувати методичні рекомендації щодо їі організації, розроблені науковцями і методистами в умовах традиційного навчання, нині не є можливим, оскільки слід врахувати нові виклики часу, зокрема співпраці педагогів зі студентами за допомогою онлайн-ресурсів.

Аналіз останніх публікацій. Організація самостійної роботи студентів як наукова проблема завжди перебувала у центрі досліджень вітчизняних авторів. Роль самостійної роботи в освітньому процесі було порушено у праці С. Цюри, А. Такзалової [7]; важливим проблемам організації самостійної роботи студентів у закладах вищої освіти присвячено статтю I. Шимка [8]; питання підвищення ефективності самостійної діяльності здобувачів освіти висвітлено в публікації О. Нестеренко [4]; методи організації самостійної роботи студентів розкрито авторами О. Хміль, Л. Каськова, Д. Хміль, Е. Колот, О. Бережна, Ю. Солошенко [6]; різні аспекти організації самостійної роботи під час вивчення англійської мови в закладі вищої освіти присвячено публікації В. Лучкевич, Г. Кемінь [3]. Проте в науковій літературі неповною мірою відображено проблему методики організації самостійної роботи здобувачів освіти в умовах карантинних обмежень під застосування змішаної форми навчання. Це і зумовило написання цісї статті.

Метою статті $\epsilon$ 3'ясування особливостей методики організації самостійної роботи студентів в умовах карантинних обмежень під час світової пандемії.

Виклад основного матеріалу. Як зазначено в Законі України “Про вищу освіту”, самостійна робота студентів є однією з найважливіших форм організаціх освітнього процесу у закладі вищої освіти. Зокрема, в ст. 50 цього закону вказано, що “освітній процес у закладах вищої освіти здійснюється за такими формами: навчальні заняття; самостійна робота; практична підготовка; контрольні заходи" [1]. Проблема самостійної роботи студентської молоді була і залишається актуальною в різні періоди становлення і розвитку середньої і вищої освіти в Україні. У науковій літературі самостійна робота студентів визначається як однин з найважливіших компонентів навчання, який становить інтеграцію різних видів колективної та індивідуальної освітньої діяльності, що реалізується в ході аудиторних i позааудиторних занять під педагогічним керівництвом викладача або самостійно студентами без його участі [6].
Виходячи 3 визначення поняття “самостійна робота студентів”, розуміємо, що вона може мати три варіанти с прояву: по-перше, це самостійне виконання студентами різноманітних завдань на вимогу викладача під час проведення аудиторних занять (лекцій, практичних чи лабораторних); подруге, самостійне виконання студентською молоддю завдань, проєктів, підготовка презентацій, наукових повідомлень, ментальних мап в позааудиторний час; по-третє, науководослідницька діяльність студентів, що виникає у ході підготовки наукових робіт (курсових, кваліфікаційних), написання тез, статей, конкурсних завдань та творчих проєктів.

Питома вага самостійної роботи в різні періоди розвитку вищої освіти змінювалася. У 90-х р. минулого століття відводилося 70 \% часу на аудиторні заняття, а 30 \% на самостійну роботу. Потім на початку 2000 р. у методичних рекомендаціях закладам вищої освіти пропонувалося змінити пропорцію $50 \%$ на $50 \%$, а вже в наш час, на початок 20-х р. XXI ст., самостійна робота може складатися з 70 \% від загальної кількості відведеного часу на вивчення навчальних дисциплін, а на аудиторні заняття лише 30 \%. А це означає, що зменшення аудиторного навантаження зумовлює підвищення ролі активності студентів, формує у них здатність самостійно працювати, самонавчатися, саморозвиватися, професійно зростати. Розвиток самостійності сприяє формуванню вміння самому керувати процесом самостановлення особистості, усвідомлювати сильні й слабкі свої сторони, визначати конкретні завдання та успішно їх розв'язувати. Як вважає О. Нестеренко, підготовка студента до самостійної роботи має пройти кілька стадій: від “отримання інформації до знання, а потім - до розуміння, які потрібно перетворити в керівництво для практичних дій” $[4,79]$. Автор підтримує думку науковців, зокрема I. Шимко $[8,36]$, про те, що існують різні види самостійної діяльності студентів - підготовка до лекційних, практично-лабораторних занять, контрольних заходів (заліків, іспитів, написання рефератів, курсових та кваліфікаційних проектів). Залежно від форми самостійної роботи вчені розглядають такі традиційні ії види: під час лекції відбувається активне слухання студентів та конспектування окремих теоретичних положень; практичних занять - виконання завдань, розв'язання задач; лабораторних робіт підготовка і проведення експерименту, обробка його результатів; семінарських занять - виступи 3 науковими повідомленнями, доповідями, рецензіями, участь в дискусіях. У ході 
позааудиторної самостійної роботи відбувається розв'язання практичних завдань, задач, самостійне опрацювання наукових джерел $[4,80]$.

Починаючи з 2020 р., у зв'язку зі всесвітньою пандемією, Міністерство освіти і науки України запропонувало закладам вищої освіти поступовий перехід до змішаного навчання. У рекомендаціях МОН України зазначено, що в умовах карантинних обмежень слід “трансформувати звичні види занять у форми взаємодії суб'єктів навчання, що можуть здійснюватися синхронно та асинхронно, а також в організовану самостійну роботу студента" $[5,35]$. А це означає, що викладач має відійти від традиційних організаційних форм і видів навчання зі студентами, не здійснювати чіткий поділ на лекційні, практичні, семінарські, лабораторні заняття, а свою роботу планувати як своєрідний набір діяльностей: аудиторно з безпосередньою участю викладача і студентів (контактні години) та через опосередковану взаємодію викладача $\mathrm{i}$ студентів засобами онлайн-технологій (онлайндіяльність). Онлайн-діяльність здійснюється синхронно, коли всі учасники освітнього процесу на зв'язку одночасно (відеоконференція, вебінар) або асинхронно, коли студенти ознайомлюються 3 матеріалами і виконують самостійно завдання в різний час (форум, чат, Google клас тощо). Найбільш ефективними інструментами, як вважають сучасні студенти, $є$ засоби відеозв'язку (ZOOM, Skype, Meet та інші), месенджери (Viber, Messenger, Telegram та інші), віртуальні освітні середовища (Moodle та інші) [2].

Враховуючи перехід у навчанні студентів на змішану форму, яка може поєднувати аудиторну та дистанційну роботу, зазначимо, що збільшується питома вага самостійної діяльності студентів. Щоб вона стала успішною, викладачеві необхідно провести значну підготовчу роботу та озброїти студентів ефективними методами навчання. Як зазначено у вищезгаданих рекомендаціях, змішане навчання передбачає кілька етапів, перший з яких отримав назву попередньої підготовки, мета якої полягає в усвідомленні викладачем і студентами способів планування ефективного навчання. На цьому етапі важливу роль відіграють мотиваційні матеріали, які зможуть зацікавити студентів опановувати новий матеріал із дисципліни. Викладач може запропонувати виконати тест, який допоможе виявити рівень знань студентів із попередньої теми та надати рекомендації щодо наукових джерел $з$ теми, яка буде вивчатися, вказати на те, як краще спланувати час та дібрати практичний матеріал для розуміння теоретичних положень. На цьому етапі можна здійснювати такі види освітньої діяльності: під час контактних годин - опитування, виконання самостійної роботи; онлайн-діяльності - ознайомлення, вивчення або повторення базової термінології $з$ теми, перегляд промовідео (підготовленої раніше викладачем презентації), діагностичне тестування, огляд інфоргафіків (графіки, схеми, діаграми з інформаційним наповненням).

Другий етап - вивчення нового матеріалу (інформації), може здійснюватися в дедуктивний чи індуктивний спосіб, перший з яких вимагає ознайомлення 3 новими теоретичними положеннями, правилами, закономірностями, а потім встановлення зв'язків 3 практикою; другий, навпаки, - передбачає спочатку виконання практичних завдань, на основі яких студенти, узагальнюючи, формулюють теоретичні відомості. Під час цього етапу в умовах контактних годин учасникам освітнього процесу пропонується здійснювати такі методи та види освітньої діяльності, як презентація, обговорення кейсів (метод конкретних ситуацій, ситуаційного аналізу), пошук відповідей на запитання для самопідготовки. А онлайн-діяльність здійснюється через віде-, аудіозаписи, презентації, роботу з кейсами, відеоконференції, постановку проблемних запитань під час спілкування зі студентами.

Наступним етапом може стати тренування, суть якого полягає у виконанні практичних завдань у межах виучуваної теми та може здійснюватись як синхронно, так і асинхронно. Рекомендується на цьому етапі у межах контактних годин запроваджувати методи й види діяльності, пов'язані з обговоренням окремих питань теми, проведенням дебатів, дискусій, рольових ігор, виконанням практичних групових/індивідуальних завдань не на оцінку. А в ході онлайн-навчання пропонують вдаватися до таких же самих методів і видів навчання, тільки залучаючи чати, форуми.

Важливим етапом у змішаному навчанні $\epsilon$ виконання практичних завдань, яке здійснюється як синхронно, так й асинхронно, індивідуально й у творчих групах. Під час формулювання умов до практичних завдань викладач повинен враховувати, які очікувані результати мають отримати студенти. У ході контактних годин варто звертати увагу на виконання практичних та лабораторних завдань. Онлайн-навчання передбачає самостійний пошук студентами відповідей на запитання, виконання віртуальних лабораторних робіт, різнорівневих індивідуальних та групових, інтерактивних практичних завдань тощо. 
Важливим етапом у змішаному навчанні $\epsilon$ також рефлексія, яка виступає своєрідним підсумком усієї попередньої роботи, що становить собою самостійно зроблений студентом висновок про засвоєння матеріалу, його цінність для подальшого навчання та майбутньої професійної діяльності. Студент самостійно проводить самоаналіз, що він нового дізнався 3 навчальної дисципліни, які вміння і навички сформував і над чим йому необхідно продовжити працювати в найближчому майбутньому. Учені пропонують на цьому етапі використовувати такі методи і види навчальної діяльності, як: під час контактних годин це можуть бути діалог, групове обговорення, короткі письмові або усні відповіді на запитання викладача; у ході онлайн-діяльності ефективним може стати розроблення нотаток до лекцій, карт пам'яті, ведення щоденника, відповіді на рефлексивні запитання, презентації тощо.

Змішане навчання студентам дає унікальну можливість підвищити рівень своєї самостійності у вивченні нового матеріалу з будь-якої навчальної дисципліни. Цінною роботою у цьому напрямі може стати попередня підготовка викладачем текстів опорних лекцій, які потребуватимуть розширення, доповнення, добору практичних прикладів самими студентами під час самостійного опрацювання їх у домашніх умовах. 3 цією метою викладач навмисне виділяє певним кольором у тексті лекції окремі положення, що потребують самостійного доопрацювання, ставить перед студентами конкретні завдання і у визначений час через зворотний зв'язок проводить перевірку самостійного виконання цих завдань.

Під час вивчення теоретичного матеріалу в онлайн-режимі викладач детально 3'ясовує основні положення нової теми без звернення до наочних засобів, а натомість пропонує студентам синхронно у ході ознайомлення скласти структурно-логічну схему, порівняльну таблицю, карту пам'яті, а вкінці заняття прозвітувати. Виконання такого завдання сприятиме розвитку у студентів логічного мислення, виділення головного й другорядного з виучуваної теми, прийняттю самостійних рішень або встановленням зв'язку між теоретичним і практичним матеріалом.

Традиційно самостійна робота в аудиторії організовувалася чотирма способами: за зразком, реконструктивно, варіативно, творчо [3]. Реконструктивна самостійна робота - це діяльність студента на основі використання опосередкованого чи свого досвіду та інтелектувальних дій 3 метою перетворення навчального матеріалу відповідно до певних вимог. Наведені вище приклади організації самостійної роботи зі студентами в контактні години і належать до реконструктивного способу.

Самостійна робота студентів варіативного характеру розглядається як сформоване уміння самостійно проаналізувати навчальну ситуацію, виділити головне і другорядне, виокремити й узагальнити важливі положення, що потребують конкретного розв'язання, акцентувати увагу на окремих проблемних аспектах. До прикладу можна запропонувати студентам в умовах онлайндіяльності опрацювати додаткову наукову літературу до нової теми, зробити її огляд, вказавши на різні позиції авторів щодо конкретних питань лекції, а також обгрунтувати власну позицію, доповнивши матеріалом конспект лекції, запропонований викладачем у ході контактного заняття.

Творча самостійна робота потребує найвищого прояву самостійності студентів та їхньої пізнавальної активності. На основі засвоєних теоретичних положень студент пропонує власний погляд на розв'язання важливих аспектів виучуваної теми та розробляє оригінальний проєкт, відео-презентацію, інфографіку, есе тощо.

У другому семестрі 2019-2020 навчального року в Черкаській медичній академії було проведено анонімне анкетування серед студентів бакалаврату та магістратури з метою виявлення позитивних і негативних сторін організації самостійної роботи під час карантину. Анкетуванням охоплено 86 здобувачів освіти. Серед найефективніших видів самосійної роботи студенти назвали роботу з науковою літературою (48 \%), підготовку та виконання текстових завдань, розв'язування задач, проблемних ситуацій в онлайн-режимі (31\%), роботу 3 розширення конспекту лекцій (14\%), розроблення відеопрезентацій (7 \%). Другим запитанням стало: чи збільшилась питома вага самостійної роботи у зв'язку з переходом на змішане навчання? Переважна більшість респондентів, відповідаючи на це запитання анкети, зазначили, що “Так” (62 \%). “Частково” відповіли 33 \%. Відповідь “Нi”, відзначили 5 \% учасників анкетування. Одне із запитань анкети вимагало виявити, яким інструментарієм найзручніше користуватися під час онлайн-навчання. Студенти вважають, що найефектинішими засобами є відеозв'язок через Gool Meet (49\%), онлайн-платформа Google клас (38\%), месенджери Viber, Telegram (7 \%) та електронна пошта (6 \%). На запитання анкети: “Що заважало Вам в організації самостійної роботи в умовах карантинних обмежень?”, значна частина студентів зазначили “Слабкість Інтерт- 
зв'язку” (41 \%), 23 \% учасників вказали на перевантаження завданнями 3 окремих навчальних дисциплін. Однією 3 причин неефективності в організації самостійної роботи студенти вважають недостатню кількість наукових джерел, розміщених в електронному доступі (11\%). Важливим запитанням анкети було з'ясування ефективних форм контролю за організацією самостійної роботи. На думку студентів, найефективнішою формою контролю $\epsilon$ тестування (58 \%), індивідуальні співбесіди в онлайн-режимі (26\%), письмові звіти про виконання самостійної роботи (16\%). Запитання анкети стосувалися не конкретної навчальної дисципліни, а всіх дисциплін загалом, тому відповіді мали узагальнений характер. Наші спостереження та відповіді студентів на анкету засвідчили той факт, що поширений у минулому вид самостійної роботи за зразком повністю втратив актуальність, оскільки в умовах карантинних обмежень викладачі пропонували інші завдання, які не пов'язані зі зразками. А також, під час анкетування було встановлено, що організація самостійної діяльності студентів науково-дослідницького характеру майже нічим не відрізнялась методикою організації в умовах карантинних обмежень від традиційного навчання. Серед побажань щодо поліпшення організації самостійної роботи здобувачів освіти було вказано вдосконалення навчальнометодичного забезпечення з фахових дисциплін та підготовку методичних рекомендацій до організації самостійної роботи 3 вибіркових дисциплін.

Висновки і перспективи подальших розвідок. Отже, в умовах карантинних обмежень під час всесвітньої пандемії самостійна робота студентів активізувалася, проте, вона набула специфічних особливостей у зв'язку з тим, що навчання у закладах вищої освіти стало змішаним i це дало можливість поєднувати аудиторні заняття (контактні години) з онлайн-діяльністю через дистанційне навчання. Нами встановлено особливості методики організації самостійної роботи студентів у порівнянні $з$ традиційним навчанням. Подальшого дослідження потребує такий важливий аспект, як організація самостійної роботи студентів у творчих групах під час онлайндіяльності.

\section{ЛIТЕРАТУРА}

1. Закон України “Про вищу освіту”. URL: https:// zakon.rada.gov.ua/laws/show/1556-18\#Text

2. Інформаційно-аналітична довідка про результати опитування щодо стану використання технологій дистанційного навчання у закладах вищої освіти
України. URL: https://www.sqe.gov.ua/images/ materials

3. Лучкевич В.В., Кемінь Г.М. Організація самостійної роботи студентів у процесі навчання іноземної мови у вищій школі. Вісник Чернігівського начіонального педагогічного університету. Педагогічні науки. 2013. Вип. 108.2. URL: http:// nbuv.gov.ua/UJRN/Vchdpu P $2013 \quad 2 \quad 108 \quad 44$

4. Нестеренко О.Б. Підвищення ефективності самостійної роботи студентів. Міжнародний науковий журнал “Інтернаука”. Серія: Педагогічні науки. №14 (36), 2017. С. 78-82

5. Рекомендації щодо впровадження змішаного навчання у закладах фахової перед вищої та вищої освіти. Міністерство освіти і науки Украӥни. URL: https://mon.gov.ua/storage/app/media/vishcha-osvita/ 2020/zmyshene\%20navchanny/zmishanenavchanniabookletspreads-2.pdf

6. Хміль О.В., Каськова Л.Ф., Хміль Д.О., Колот Е.Г., Бережна О.Е. Солошенко Ю.І. Методи організації самостійної роботи в сучасному навчанні студентів. Іноваційні технологї̈ в організаиії самостійної роботи студентів медичних освітніх закладів: матеріали навч.-наук. конф. з міжнар. участю. м. Полтава, 23 березня 2017 р. С. 176-177.

7. Цюра С., Терзалова А. Нормативне закріплення понять “освітне середовище", “освітній простір", “освітній процес" у контексті педагогічної термінології. Молодь і ринок: щуомісячний науково-педагогічний журнал. №5/184. 2020. С. 111-118. URL: http:// mir.dspu.edu.ua/index.php/2308-4634/issue/view/13562

8. Шимко І. Проблеми організації самостійної роботи у вищій школі. Рідна школа. 2005. №8. С. 34-35.

\section{REFERENCES}

1. Zakon Ukrayiny "Pro vyshhu osvitu" [Law of Ukraine "On Higher Education"]. Available at: https:// zakon.rada.gov.ua/laws/show/1556-18\#Text [in Ukrainan].

2. Informatsiino-analitychna dovidka pro rezultaty opytuvannia shchodo stanu vykorystannia tekhnolohii dystantsiinoho navchannia u zakladakh vyshchoi osvity Ukrainy [Information and analytical report on the results of the survey on the state of use of distance learning technologies in higher education institutions of Ukraine]. Available at: https://www.sqe.gov.ua/images/materials/ [in Ukrainian].

3. Luchkevych, V.V. \& Kemin, G.M. (2013). Orhanizatsiia samostiinoi roboty studentiv u protsesi navchannia inozemnoi movy u vyshchii shkoli [Organization of independent work of students in the process of learning a foreign language in high school]. Bulletin of Chernihiv National Pedagogical University. Pedagogical sciences. No.108.2. Available at: http://nbuv.gov.ua/UJRN/ VchdpuP 20132108 44[in Ukrainian].

4. Nesterenko, O.B. (2017). Pidvyshchennia efektyvnosti samostiinoi roboty studentiv [Improving the efficiency of independent work of students]. International scientific journal "Internauka". Series: Pedagogical sciences. No. 14 (36), pp. 78-82. [in Ukrainian].

5. Rekomendatsii shchodo vprovadzhennia zmishanoho navchannia u zakladakh fakhovoi pered vyshchoi ta 


\section{ТЕАТРАЛЬНЕ ЖИТТЯ ЛЬВІВСЬКОЇ ГРЕКО-КАТОЛИЦЬКОЇ ДУХОВНОЇ СЕМІНАРІЇ КІНЦЯ ХУІІІЕРШОЇ ПОЛОВИНИ ХІХ СТ.}

vyshchoi osvity [Recommendations for the introduction of blended learning in vocational institutions before higher and higher education]. Ministry of Education and Science of Ukraine. Available at: https://mon.gov.ua/storage/app/ media/vishcha-osvita/2020/zmyshene \%20navchanny/ zmishanenavchannia-bookletspreads-2.pdf[in Ukrainian].

6. Khmil, O.V., Kaskova, L.F., Khmil, D.O., Kolot, E.H. Berezhna, O.E. \& Soloshenko, Yu.I. (2017). Metody orhanizatsii samostiinoi roboty v suchasnomu navchanni studentiv [Methods of organizing independent work in modern student learning]. Inovatsiini tekhnolohii v orhanizatsii samostiinoi roboty studentiv medychnykh osvitnikh zakladiv: materialy navch.-nauk. konf. z mizhnar. uchastiu. m. Poltava, 23 bereznia 2017 r. Innovative technologies in the organization of independent work of students of medical educational institutions: Proceedings of the Educational Sciences. Conf. with international participation. Poltava, March 23, 2017. (pp. 176-177). Poltava. [in Ukrainian].

7. Tsiura, S. \& Terzalova, A. Normatyvne zakriplennia poniat "osvitnie seredovyshche", "osvitnii prostir", "osvitnii protses" u konteksti pedahohichnoi terminolohii [Normative consolidation of the concepts "educational environment", "educational space", "educational process" in the context of pedagogical terminology]. Youth and the market: a monthly scientific and pedagogical journal. No.5 / 184. 2020.pp. 111-118. Available at: http://mir.dspu.edu.ua/ index.php/2308-4634/issue/view/13562 [in Ukrainian].

8. Shymko, I. (2005). Problemy orhanizatsii samostiinoi roboty u vyshchii shkoli [Problems of organizing independent work in high school]. Native school. No. 8. pp. 34-35.[in Ukrainian].

Стаття надійшла до редакції 04.01.2021

УДК [792.054:[378.6:271.4]](477.83-25)“1794/1848”

DOI:

Мирослава Циганик, кандидат філологічних наук, доиент кафедри театрознавства та акторської майстерності Львівського національного університету імені Івана Франка

\section{ТЕАТРАЛЬНЕ ЖИТТЯ ЛЬВІВСЬКОЇ ГРЕКО-КАТОЛИЦЬКОЇ ДУХОВНОЇ СЕМІНАРІЇ КІНЦЯ ХVІІІ ПЕРШОЇ ПОЛОВИНИ ХІХ СТ.}

У статті проаналізовано театральну діяльність у стінах Львівської духовної семінарії грекокатоличького обряду в 1794-1848 рр., зазначено тогочасні суспільно-політичні умови, в яких перебувала освіта греко-католищької семінарії у Львові кіния XVIII першої половини ХIX ст. Вказано на основні принципи естетичного виховання семінаристів засобами сиенічного мистеитва. Названо видатні постаті, які під час навчання в семінарії розвинули свої мистецькі здібності та відіграли важливу роль у розвитку украйнського професійного театру в Галичині.

Ключові слова: Греко-католицька духовна семінарія; семінаристи; сценічне мистецтво; українське культурне відродження; театр; “Маркіянове сузір'я”; Рудольф Мох; драма.

Jim. 16.

Myroslava Tsyhanyk, Ph.D.(Philology), Associate Professor of the Theater Studies and Acting Department, Ivan Franko National University of Lviv

\section{THEATRE LIFE OF THE GREEK-CATHOLIC SEMINARY IN LVIV IN THE LATE XVIII CENTURY - THE FIRST HALF OF THE XIX CENTURY}

The article analyzes the theatrical activity of Greek Catholic Theological Seminary in Lviv in 1794-1848, points out the basic principles of teaching the performing arts of seminarians, indicates the then socio-political conditions in which the formation of the Greek Catholic Theological Seminary in Lviv late XVIII first half of the XIX century. The prominent figures that developed their artistic abilities during their studies at the seminary and played an important role in the development of the Ukrainian professional theater in Galicia are named.

Since its establishment in 1873 and till the start of the democratic revolution in the Austrian Empire in 1848, the Greek-Catholic Seminary in Lviv appeared to be at the core of shaping and developing of the artistic tendencies among the nationally conscious Ukrainian youth. Additionally, it happened to be an epicenter of the National Revival, a home for the "Ruthenian Triad" and, in the course of time, the alma mater of the Ukrainian dramaturgy. The dramatic arts'inception found its beginning in 1874 when F. Bogomolets 'play in Polish was put on a performance. Under the guidance of A. Angelovich, the seminarists have been working on learning Ukrainian language, exploring songs and rites. Meanwhile, until 1797, they have been leading a dynamic theatrical life in the Seminary, the key manifestation of which may be found in various scenes staged throughout the holy tides. After the lull, which lasted for more than three decades, the Greek Catholic Theological Seminary in Lviv revived its performances in 1829. Despite the difficult livelihood and the fact, that the cholera epidemic has arisen in Galicia exactly at a time, even 